\title{
POTRET PERJUANGAN TOKOH UTAMA MENGHADAPI KONFLIK KEHIDUPAN DALAM NOVEL SIRKUS POHON KARYA ANDREA HIRATA
}

\author{
Fathin Najla \\ Universitas Muhammadiyah Malang \\ Fathinnajla@gmail.com
}

\begin{abstract}
Abstrak:
Penelitian pada novel ini penting untuk dilakukan sebagai pengejawantahan nilai-nilai kehidupan yang ada di dalam karya sastra sehingga masyrakat mampu memahami dengan mudah bahwa nilai-nilai kehidupan yang ada berusaha di trasnsformasikan dalam bentuk karya sastra. Jadi karya sastra bukan hanya keindahan semata. Tetapi ada nilai-nilai yang bisa dijadikan pembelajaran dalam hidup. Metode yang digunakan dalam penelitian ini adalah metode kualitatif. Metode kualitatif memberikan perhatian terhadap data alamiah, data dalam hubungannya dengan konteks keberadaannya. Cara-cara inilah yang mendorong metode kualitatif dianggap sebagai multimetode sebab penelitian pada gilirannya melibatkan sejumlah besar gejala sosial yang relevan.Kesimpulan dari tulisan ini adalah bahwa setiap orang pasti memiliki permasalahan dalam hidupnya dan tidak akan pernah bisa diselesaikan jika tidak ada usaha untuk merubah. Setiap orang pun akan selalu membutuhkan orang lain dalam hidupnya karena pada dasarnya manusia adalah mahluk sosial yang tidak bisa hidup sendiri tanpa bantuan orang lain. Andrea Hirata dengan sangat baik menyampaikan proses kehidupan tersebut dalam sebuah cerita inspiratif yang dikemas dalam novel bertajuk Sirkus Pohon.
\end{abstract}

Kata Kunci: karya sastra, representasi tokoh

\section{PENDAHULUAN}

Karya sastra merupakan media yang digunakan oleh pengarang untuk menyampaikan gagasan-gagasan dan pengalamannya. Peran karya sastra sebagai media untuk menghubungkan pikiranpikiran pengarang untuk disampaikan kepada pembaca. Setiap kali membaca karya sastra, pembaca pasti tidak hanya bertujuan untuk membaca alur ceritanya saja, tetapi pembaca juga akan mempertanyakan apa yang ingin diungkapkan pengarang melalui karyanya atau apa makna yang terkandung melalui isi cerita tersebut. Sastra merupakan sebuah seni. Seni mau tidak mau berkaitan dengan keindahan dan lingkup sosial.

Karya sastra memiliki banyak hasil karya yang memiliki identitas yang berbeda-beda, novel merupakan salah satu karya sastra yang banyak dijadikan 
pengarang atau sastrawan untuk mengejawantahkan sebuah makna, budaya, atau cerita kehidupan dengan mengemasnya dalam sebuah bahasa yang berbentuk cerita. Setiap novel yang ditulis pengarang pasti memiliki pesan-pesan tersendiri yang mampu dimaknai pembaca. Salah satunya adalah novel Sirkus Pohon karya Andrea Hirata yang menyuguhkan tokoh utama sebagai seseorang yang memiliki liku kehidupan yang cukup terjal, shobirin sebagai tokoh utama digambarkan sebagai seorang pemuda yang kehilangan arah dalam menjalani kehidupan.

Pengarang menggambarkan bahwa adanya ruang kosong dalam diri tokoh sehingga tokoh tersebut tidak memiliki semangat untuk menjalani hidup, tetapi segalanya berubah ketika tokoh utama tersebut berhasil menemukan cinta yang akhirnya menjadi alasan untuk berubah, membangkitkan semangat hidupnya, bahkan banyak menemukan jalan-jalan kehidupan ditengah kesulitan yang dihadapi.

Andrea Hirata menyuguhkan sebuah kisah yang sangat memiliki nilai-nilai kehidupan yang isnpiratif. Penelitian pada novel ini penting untuk dilakukan sebagai pengejawantahan nilai-nilai kehidupan yang ada di dalam karya sastra sehingga masyrakat mampu memahami dengan mudah bahwa nilai-nilai kehidupan yang ada berusaha di trasnsformasikan dalam bentuk karya sastra. Jadi karya sastra bukan hanya keindahan semata. Tetapi ada nilai-nilai yang bisa dijadikan pembelajaran dalam hidup.

Shobirin merupakan tokoh utama dalam novel Sirkus Pohon karya Andrea Hirata. Diceritakan dalam novelnya bahwa shobirin merupakan seorang pemuda yang memiliki empat saudara dengan kondisi pendidikan yang berbeda-beda. Shobirin sendiri hanya menempuh pendidikan hingga bangku 2 SMP saja, artinya shobirin hanya memiliki ijazah SD. Shobirin terpaksa berhenti sekolah karena karena keadaan ekonomi dan kenakalan shobirin yang tidak bisa diatasi pada masa itu hingga akhirnya shobirin berteman dengan pemuda-pemuda yang kurang baik dalam bersikap hingga menghantarkan shobirin untuk berhenti dari bangku pendidikan karena terpengaruh perangai buruk dari sekawanannya.

Saudara-saudara shobirin memiliki latar belakang yang berbeda dengan shobirin, abang tertuanya adalah seorang yang pandai,dan terpandang di jurusan Tambang Sekolah Teknik PN Timah dan terpandang di pekerjaan. Abang keduanya adalah orang yang pendiam, juru ukur, juga di PN. Bicaranya sedikit-sedikit, selalu ingin dipandang bahwa ia adalah abang. Abang ketiganya adalah seorang 
pegawai kantor Syahbandar, telah diangkat menjadi PNS. Dia kalem, tegak, tersenyum santai, tapi jaga wibawa. Dan adik bungsunya adalah perempuan yang suka menindas suaminya, seorang wanita yang selalu menuntut lebih kepada suaminya.

Latar belakang kisah tersebut yang memicu munculnya sebuah konflik kehidupan dalam perjalanan hidup shobirin sebagai tokoh utama. Perbedaan strata dan status menjadi sebuah permasalahan yang menghantui hidup shobirin, karena perbedaan-perbedaan itulah shobirin merasa tidak memiliki tujuan hidup dan keberhasilan dalam hidupnya. Ia menganggap bahwa ia akan tetap menjadi seorang yang berkecimpung dengan dunia pekerjaan serabutan yang entah kapan akan berakhir. Latar belakang keluarga menjadi faktor utama mengapa shobirin begitu memandang sebelah mata terhadap hidupnya.

\section{KAJIAN PUSTAKA}

Semiotika memberi jalan keluar dengan cara mengembalikan objek sekaligus pada pengarang dan latar belakang sosial yang menghasilkannya. Argumentasi yang dikemukakan dalam teori semiotika adalah asumsi bahwa karya seni merupakan proses komunikasi, karya seni dapat dipahami semata-mata dalam kaitannya dengan pengirim dan penerima.
Semiotika sosial menurut salah seorang pelopornya, yaitu Halliday (1992:3-8), adalah semiotika itu sendiri, dengan memberikan penjelasan lebih detail dan menyeluruh tentang masyarakat sebagai makrostruktur.

Apabila analisis ekstrinsik terbatas dalam memberikan penjelasan pada aspek tekstual, unsur-unsur kemasyarakatan sebagaimana terkandung dalam karya, yang kemudian dikaitkan dengan masyrakat dalam kenyataan sehari-hari, semiotika sosial melangkah lebih jauh, di satu pihak mencoba memberikan penilaian pada gejala di balik objek, dilain pihak memberikan kemungkinan untuk menjelaskan hakikat masyrakat dalam rangka multidisiplin, sebagai multikultural. Halliday dalam hubungan ini menganggap bahwa istilah sosial sejajar dengan kebudayaan.

Semiotika sosial memiliki implikasi lebih jauh dalam kaitannya dengan hakikat teks sebagai gejala yang dinamis. Sebagai ilmu tanda, semiotika sosial mesti dipahami dalam kaitannya dengan konteks, dimana tanda-tanda tersebut difungsikan. Tanda tidak berfungsi dalam dirinya sendiri. Oleh karena itulah, baik dalam strukturalisme maupun semiotika konsep antarhubungan memegang peranan yang sangat menentukan fungsi-fungsi yang selalu diabaikan oleh para peniliti sastra. 
Sebagai gejala kesastraan, teks juga berfungsi hanya dalam pemakaian, dalam interaksi antara pengirim dan penerima. Puisi, cerpen, novel, peribahasa, dongeng, lagu, lukisan dan sebagainya berfungsi dan dengan demikian memberikan makna semata-mata dalam proses komunikasi, interaksi antara subjek dengan objek.

Jika dihubungkan dengan novel maka semiotika sosial disini berfungsi sebagai penjelas makna atau tanda-tanda yang terdapat dalam novel dalam gejala sosial yang terjadi. Seperti permasalahan sosial yang dialami tokoh utama yang bermasalah dalam kehidupannya. Semiotika sosial akan menjadi teori penjelas yang membahas secara rinci dari sudut pandang semiotika sosial. Tokoh utama memiliki banyak permasalahan dalam novel yang ditulis pengarang, tetapi permasalahan yang dominan adalah permasalahan dalam lingkup sosial.

Teori semiotika sosial cocok digunakan dalam penelitian ini untuk mengungkapkan tanda-tanda yang terdapat dalam novel dalam mengungkap gejala sosial yang ada.

\section{METODE}

Metode yang digunakan dalam penelitian ini adalah metode kualitatif. Metode kualitatif memberikan perhatian terhadap data alamiah, data dalam hubungannya dengan konteks keberadaannya. Cara-cara inilah yang mendorong metode kualitatif dianggap sebagai multimetode sebab penelitian pada gilirannya melibatkan sejumlah besar gejala sosial yang relevan. Dalam penelitian karya sastra, akan dilibatkan pengarang, lingkungan sosial dimana pengarang berada, termasuk unsur-unsur kebudayaan pada umumnya (Ratna, 2004:47)

Pengumpulan data yang akan digunakan sebagai data analisis bersumber dari novel Sirkus Pohon sebagai sumber utama diperolehnya data-data yang memperkuat adanya gejala sosial dalam novel yang ditulis Andrea Hirata. Percakapan-percakapan tokoh menjadi bukti kuatsebagai bukti-bukti adanya permasalahan yang perlu diteliti dalam konteks sosial dan psikologi dalam novel Sirkus Pohon, karena fokus penelitian ini adalah pada tokoh utama yang memiliki banyak sekali permasalahan yang kompleks dalam kehidupannya namun dapat terselesaikan karena kekuatan cinta.

Selain faktor sosial yang menjadi titik permasalahan kehidupan tokoh faktor psikologi juga memberi dampak yang signifikan terhadap keadaan tokoh utama yang dijerat berbagai permasalahan hidup. Dibuktikan dari perubahan semangat tokoh 
utama dalam menjalani hidup setelah berjumpa dengan seorang wanita yang membuat ia jatuh hati dan berubah seratus persen dalam menjalani kehidupan. Lingkup sosial dan psikologi sangat berkaitan dalam kehidupan yang diceritakan pengarang dalam novel Sirkus Pohon.

Ditengah permasalahan yang tengah dihadapi Shobirin selaku tokoh utama, mulai dara permasalahan pekerjaan, status dalam lingkungan dan keluarga menunjukkan bahwa sedang terjadi kondisi yang tidak baik dalam kehidupan shobirin. Lingkungan sosial menjadi salah satu pengaruh mengapa shobirin selaku tokoh utama diceritakan menjadi orang yang tidak berkembang dalam urusan pekerjaan dan juga status dikeluarga. Shobirin berteman dengan seseorang yang perangainya kurang baik dan malas-malasan sehingga kurang lebih shobirin terpengaruh dengan gaya hidup temannya.

Metode kualitatif diperlukan dalam penelitian ini karena cenderung menggunakan sumber data sebagai bahan penelitian. Dan data yang banyak bisa didapatkan dalam penelitian ini adalah data berupa cerita dan percakapan dalam novel.

\section{HASIL DAN PEMBAHASAN}

Di dalam novel Sirkus Pohon menceritakan sebuah konflik kehidupan dari tokoh utama yang diceritakan begitu kompleks tetapi diakhiri dengan sebuah cerita inspiratif yang berhasil menghidupkan kembali jiwa tokoh yang diceritakan tidak memiliki semanmgat hidup. Jika dianalisis menggunakan teori semiotika sosial yang mengaitkan antara hubungan tekstual karya sastra dengan masyrakat dalam kenyataan sehari-hari maka akan ditemukan sebuah hubungan yang komperhensif bahwa tokoh utama dalam novel sirkus pohon memiliki nilai sosial yang tinggi, terbukti dari bagaimana dia menghargai temannya yang bahkan dianggap seluruh masyarakat adalah orang yang buruk. Bahkan ketika tokoh utama sudah tau bagaimana tabiat buruk temannya dia tetap berteman dengan baik. Baginya persoalan sikap dan cara hidup bukan sebuah permasalahan meskipun itu tidak baik.

Shobirin digambarkan pada sebuah cerita bahwa ia pernah mencoba percaya pada orang-orang yang bersikap baik di hadapannya, ketika ia membutuhkan pertolongan nyatanya tak ada satupun dari mereka yang berusaha menolong dan membantu shobirin dalam kesusahan. Justru yang datang menolong dan membantu shobirin adalah taripol, sosok teman yang dianggap sebagai orang yang buruk oleh semua orang. Dari peristiwa tersebut secara tidak langsung batin atau 
perasaan shobirin menyimpulkan bahwa sesorang yang baik bukanlah yang terlihat baik tetapi yang berusaha tetap berbuat baik meskipun dipandang buruk.

Shobirin selaku tokoh utama digambarkan memiliki permasalahan dalam hubungannya dengan lingkup sosial. Seperti dalam kutipan novel diceritakan bahwa Shobirin menyukai seorang gadis yang bekerja di sebuah toko, namun karena Shobirin dikenal sebagai pemuda yang tidak baik maka pemilik toko pun selalu melarang gadis itu untuk bertemu Shobirin

"Dinda bekerja menjadi penjaga toko sembako. Lantaran namaku sudah coreng, Kak Tina, juragan toko, senantiasa melindunginya. Jika aku kesana, Kak Tina tajam menatapku seperti aku mau mencuri jemuran kutangnya" (Hirata, 2017:41)

Dalam kutipan tersebut memiliki makna bahwa Shobirin merupakan pemuda yang dipandang buruk oleh masyrakat sekitar, bahkan meskipun pemilik toko itu hanya sebatas juragan ikut serta melarang pegawainya untuk dekat dengan Shobirin. Artinya karena perangai Shobirin dimata masyrakat sudah terlalu tercoreng sehingga banyak yang bersikap seperti itu.

Selain hubungannya dengan masyrakat yang tidak baik, Karir Shobirin dalam pekerjaan pun juga tidak begitu baik. Banyak tempat ia melamar kerja selalu memberi penolakan, selain karena riwayat pendidikan Shobirin yang tidak jelas juga karena riwayat kehidupan Shobirin yang terkenal tidak baik dalam masyrakat, seperti dalam kutipan novel berikut

"akan tetapi semua pintu tertutup. Mencari pekerjaan sudah sulit bagiku sebelum skandal corong TOA, apalagi setelah itu. aku terhalang reputasi yang buruk dan teradang kata-kata keramat "SMA atau sederajat". Namun halangan reputasi itu paling berat. Ada toko yang di kacanya ada karton bertulisan "Menerima karyawan", tanpa tambahan kalimat keramat itu, begitu aku lewat, seseorang lekas lekas-lekas membalikkan karton itu." (Hirata, 2017:45)

Dari kutipan-kutipan novel diatas cukup memberi gambaran bahwa betapa kompleks permasalahan Shobirin selaku tokoh utama dalam novel. Mulai dari hubungan dengan masyrakat hingga pekerjaan yang tak kunjung ia dapatkan. Tetapi karena kehadiran Dinda dalam hidup Shobirin membuat ia berhenti putus asa dan memiliki semangat bangkit untuk menata hidupnya kembali. Dinda menjadi semangat yang sangat banyak mendorong Shobirin untuk tetap semangat mencari 
pekerjaan. Disinilah faktor psikologi mulai berperan, seperti dalam kutipan novel

"berbulan-bulan aku berusaha, nihil. Nyaris aku putus asa. Satu-satunya yang membuatku bertahan hanya Dinda. Binar mata dan sipu malunya, serta masa depan kami yang terbentang di depan sana, memberiku semangat tak terbatas" (Hirata, 2017:46)

Dari kutipan diatas menjelaskan bahwa mulai ada transformasi perubahan dalam diri tokoh utama. Karena kesuakaannya kepada gadis itu tokoh utama menjadi semangat mencari kerja meskipun citranya dikalangan masyarakat sudah buruk dan mencari pekerjaan baginya amatlah susah. Tapi ia tidak pernah menyerah hingga akhirnya keberuntungan dan usahanya membawa ia pada sebuah pekerjaan

"kata ibu, jika aku diterimanya bekerja, untuk sementara ibu tak bisa memberi gaji yang besar. Tidak ada pula tunjangan transportasi atau tunjangan kesehatan karena usahanya masih usaha kecil saja dan baru mau buka. Namun semuanya akan berubah jika usahanya berkembang lagi. Karyawan dapat tinggal di tempat kerja." (Hirata, 2017:47)

Kutipan tersebut merupakan bentuk kesenangan dari shobirin karena sudah mendapatkan pekerjaan meskipun belum seberapa gajinya. Setidaknya ittu merupakan bentuk usaha shobirin karena seorang gadis yang ia sukai. Terlebih ketika Dinda berkata bahwa Shobirin harus mendapatkan pekerjaan tetap. Karena itulah Shobirin begitu antusias dan semangat

"aku ada maksud denganmu, dinda" kata shobirin“maksud apa?". "aku mau melamarmu tapi aku belum bekerja tetap". "carilah kerja tetap kalau begitu" (Hirata, 2017:47)

Percakapan dalam novel tersebut menunjukkan bahwa Shobirin berusaha merubah hidupnya karena jatuh hati pada seorang gadis. Karena perasaan itulah Shobirin berusaha sekuat tenaga membuktikan bahwa ia bisa mendapatkan pekerjaan tetap untuk melamarnya.

Itulah beberapa persoalan dalam novel yang mendasari penelitian ini sehingga penelitian ini perlu untuk dilakukan. Terlihat jelas hubungan sosial dan kondisi psikologi seseorang akan sangat mempengaruhi sikap dan pola hidup seseorang. Jika dikaitkan dengan teori semiotika sosial maka dapat diketahui bahwa tokoh tersebut memiliki simbolsimbol dalam bahasa yang ia gunakan dalam merepresentasikan kehidupannya sebagai seorang tokoh utama yang 
kehidupannya berantakan kemudian berusaha memperbaikinya.

Didalam novel ini cinta juga merupakan sebuah simbol penghidupan, karena digambarkan dengan jelas bagaiaman tidak berartinyan kehidupan shobirin sebelum ia mengenal dinda. Bahkan shobirin sendiri menganggap hidupnya tidak berarti. Tetapi kesan itu berubah ketika ia mengenal dan bertemu dengan dinda. Seakan ia menjadi lebih bergairah menjalani hidup dan berusaha melakukan apapun untuk bisa mendapatkan hati dinda meskipun resikonya begitu berat apalagi dalam hal mencari pekerjaan.

Dari cerita novel Srikus Pohon kita juga dapat mempelajari bahwa sebenarnya kehidupan itu teramat berarti meskipun bagi orang-orang yang kehidupannya bermasalah dan terlihat seperti tidak ada gunanya. Sebenarnya bukan kehidupan itu sendiri yang tidak berarti tetapi manusi sebagi subyek yang kehilangan semangat dan alasan untuk menjalani hidup dengan baik. Perasaan seperti itulah yang berusaha digambarkan penulis melalui seorang tokoh utama bernama Shobirin. Andrea Hirata menitipkan banyak makna dan pesan-pesan tersirat dalam setiap percakapan dan cerita para tokoh. Andrea Hirata cenderung menggabungkan berbagai macam cerita dalam satu novel agar bisa bandingkan dan memberikan wawasan kepada pembaca bagaimana sebenarnya seorang tokoh utama.

\section{KESIMPULAN}

Novel Sirkus Pohon merupakan gambaran kehidupan yang sangat mencerminkan kehidupan masyrakat. Tokoh utama digambarkan sebagai seorang yang memiliki banyak problematika kehidupan tetapi mampu diselesaikan dengan hadirnya seorang wanita yang membuatnya kembali menemukan semangat hidup lagi.

Kesimpulan dari tulisan ini adalah bahwa setiap orang pasti memiliki permasalahan dalam hidupnya dan tidak akan pernah bisa diselesaikan jika tidak ada usaha untuk merubah. Setiap orang pun akan selalu membutuhkan orang lain dalam hidupnya karena pada dasarnya manusia adalah mahluk sosial yang tidak bisa hidup sendiri tanpa bantuan orang lain. Andrea Hirata dengan sangat baik menyampaikan proses kehidupan tersebut dalam sebuah cerita inspiratif yang dikemas dalam novel bertajuk Sirkus Pohon

\section{DAFTAR PUSTAKA}

Prof. Dr. Nyoman Kutha Ratna, S. (2004). Teori, Metode, dan Teknik Penelitian Sastra. Yogyakarta: Pustaka Pelajar. 
Hirata, A. (2017). Sirkus Pohon.

Yogyakarta: Bentang Pustaka. 